ENTREPRENEURSHIP AND SUSTAINABILITY ISSUES

ISSN 2345-0282 (online) http://jssidoi.org/jesi/

2019 Volume 6 Number 4 (June)

http://doi.org/10.9770/jesi.2019.6.4(41)

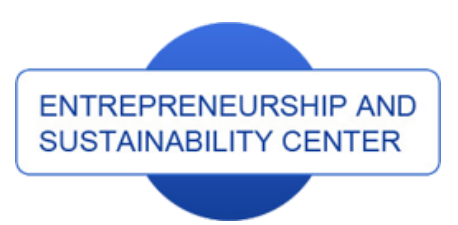

Publisher

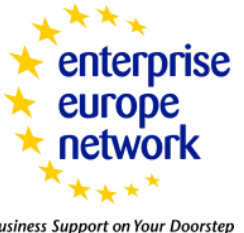

CASPA

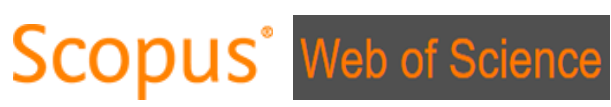

http://jssidoi.org/esc/home

Business Support on Your Doorstep

\title{
GRAPHIC MODEL FOR EVALUATING THE COMPETITIVENESS AND ECO-EFFICIENCY OF ECO-INNOVATIVE PROJECTS
}

\author{
Galimkair Mutanov', Sayabek Ziyadin², Aijaz Shaikh ${ }^{3}$ \\ 1,2 Al-Farabi Kazakh National University, 7lal-Farabi ave., Almaty, Kazakhstan \\ ${ }^{3}$ Jyväskylä University School of Business and Economics, P.O.Box 35, FI-40014, \\ University of Jyväskylä, Finland \\ E-mails:1rector@kaznu.kz ; ${ }^{2}$ sayabekz@gmail.com, ${ }^{3}$ aijaz.a.shaikh@jyu.fi
}

Received 15 February 2019; accepted 2 June 2019; published 30 June 2019

\begin{abstract}
Eco-innovation describes the creation of novel and competitively priced goods, processes, systems, services, policies, and procedures that satisfy human needs and improve the quality of life while ensuring sustainable development with minimal use of natural resources and minimal release of toxic substances. This article delves into one of the most pressing problems in improving the assessment of eco-innovative projects meant to effect sustainable development. The article also proposes new criteria for evaluating eco-innovation projects. The purpose is to develop and propose a graphic model by which to assess the innovativeness, competitiveness, and eco-efficiency of eco-innovation projects. In the development of this method, experts applied a methodological approach based on an assessment of the indicators of the innovativeness, competitiveness, and eco-efficiency of an eco-innovation project through the associated construction of a graphic model with indicators divided into nine sectors.
\end{abstract}

Keywords: graphic model; innovativeness; competitiveness; eco-efficiency; eco-innovative project; technological forecasting; comprehensive assessment

Reference to this paper should be made as follows: Mutanov, G.; Ziyadin, S.; Shaikh, A. 2019. Graphic model for evaluating the competitiveness and eco-efficiency of eco-innovative projects, Entrepreneurship and Sustainability Issues 6(4): 2136-2158. http://doi.org/10.9770/jesi.2019.6.4(41)

JEL Classifications: Q57, C29

\section{Introduction}

In recent times, the intensity of digitalization and innovative activities has largely been reflected in the level of sustainable economic development. In the global competition context, this can be seen in those countries that provide favorable economic conditions and innovation-related benefits. The development of an innovative economy is an important prerequisite to increasing the competitiveness of a country. 


\section{ENTREPRENEURSHIP AND SUSTAINABILITY ISSUES}

ISSN 2345-0282 (online) http://jssidoi.org/jesi/

2019 Volume 6 Number 4 (June)

http://doi.org/10.9770/jesi.2019.6.4(41)

It has been observed that developed countries located in the global north are consistently striving to develop technological leadership and increase the efficiency of their innovation systems. This is effectively considered to be the amount spent on the scientific research and development (popularly known as R\&D) as the percentage of the gross domestic product (GDP) of a country. Here, the performance of several countries was observed, and according to WIPO (2018), Israel took first place, spending 4.3\% of its GDP on R\&D, followed by the Republic of Korea with 4.2\%. Switzerland received a conditional "bronze" at 3.4\%; Sweden and Japan took the fourth and fifth positions with indicators of $3.3 \%$ and $3.1 \%$, respectively.

From the experience of these countries, it can be safely concluded that a national innovation system is certain to be effective and sustainable if the countries allocate enough resources, modernizing services, and manufacturing sectors and other sub-sectors of the economy and develop a positive perception of innovation among their populaces. Considering their indispensability, these innovative developments are increasingly becoming the object of close attention at not only the government level but also the regional and individual economic entity levels.

Currently, many enterprises use traditional project analysis methods based on the criterion of net present value (NPV) (Žižlavský, 2014) by discounting future cash flows with regard to the current point in time (Bente Villadsen, 2017). This traditional method is usually designed for repetitive activities that are already backed by experience, accumulated expertise, and historical data to justify estimates.

The problem government agencies, investors, and analysts attempting to assess the potential of an eco-innovative project face lies in the specifics of such projects, which are unique and usually uncertain in terms of future results. In addition, these eco-innovative projects also have a long horizon of investment. These features can cause traditional methods of evaluating projects' effectiveness to produce unreliable results largely because ecoinnovative projects do not fulfill the basic prerequisites of these traditional methods. Thus, government agencies, investors, and shareholders in innovation have a keen interest in having more modern, reliable, and appropriate tools for evaluating eco-innovative projects in developed, emerging, and developing countries.

Eco-innovation refers to the creation of novel and competitively priced goods, processes, systems, services, and procedures that can satisfy human needs and improve the quality of life with a life-cycle-wide minimal use of natural resources (material including energy carriers and surface area) per unit output and a minimal release of toxic substances (quoted in Reid and Miedzinski, 2008). According to most definitions, eco-innovation reduces the environmental effects of consumption and production activities, regardless of whether doing so is the main motivation. Taking many forms, eco-innovation varies from incremental eco-efficiency improvements to fundamental change that replaces a system (Carrillo-Hermosilla et al., 2010; Tvaronavičienè, 2018; Eddelani et al., 2019; Bohdaniuk et al., 2019; Adamczyk et al., 2019; Atari et al. 2019).

With regard to the latter, the European Commission has promoted an integrated product policy aiming to support the realization of environmental product innovations that broadly reduce all environmental effects throughout a product's life cycle. This has been conceptualized as "integrated environmental product innovation" (Triebswetter and Wackerbauer, 2008). Innovation has several roles in resource efficiency.

The disconnect between the real conditions of eco-innovative project development and the methods of analysis reveals the importance of developing a graphic model for assessing the innovativeness, competitiveness, and ecoeffectiveness of eco-innovative projects to allow for a comprehensive assessment of a project's absolute positioning. 


\section{ENTREPRENEURSHIP AND SUSTAINABILITY ISSUES}

ISSN 2345-0282 (online) http://jssidoi.org/jesi/

2019 Volume 6 Number 4 (June)

http://doi.org/10.9770/jesi.2019.6.4(41)

To date, the issues relating to evaluating the effectiveness of eco-innovative projects seem to be sufficiently developed. Evidence suggests that specialists have been devoting extensive work to this issue. For example, Jeng and Huang (2015) proposed a hybrid multiple-criteria decision-making (MCDM) method comprising the master data management (MDM) method, the decision-making trial and evaluation laboratory (DEMATEL) method, and the analytic network process (ANP) approach. Multiple-criteria sorting methods based on data coverage analysis (DEA) have been developed to evaluate research and development (R\&D) projects, as reviewed by Karasakal and Aker (2017). Dutra, Ribeiro, and de Carvalho (2014) considered issues relating to the use of the economicprobabilistic model for selecting projects and determining priorities. Their model enables the quantification of the necessary investments, potential benefits, and their inherent variability, thus providing a stochastic analysis of expected returns for projects. Similarly, Padhy and Sahu (2011) proposed a two-stage methodology based on analyzing realistic options for assessing the value of a project to increase management flexibility and a linear programming model with zero integer one to select and plan an optimal project portfolio based on the organization's goals and constraints. In some research publications (e.g., Huang et al., 2016), new models of mean variance and mean variability that consider the relationships and the temporal sequence between projects have been proposed. Likewise, Abdrakhmanova et al. (2018) noted the need to organize a phase-control system of knowledge intensity according to set quantitative and qualitative criteria in order to achieve knowledge-based results (products, technology, etc.) in innovation project implementation. Zhao, Yang, Zhao, and Zhao (2017) reviewed the influences of ecological programs in land cover change by evaluating a transition matrix and a modified land cover change dynamic model at the village level. According to Leach et al. (2018), long-term environmental research projects are a key factor in the functioning and dynamics of populations, communities, and ecosystems. Cluzel, Yannou, Millet, and Leroy (2016) adapted an eco-innovation process based on the ecodesign strategy wheel, which is proposed for use with a working group of internal technical experts.

Nevertheless, the continuous expansion of the role knowledge plays in ensuring the effective functioning of innovative economic systems and the low rates of commercialization of R\&D results in scientific, technical and manufacturing spheres requires a logical continuation of research in this direction. Therefore, it is necessary to clarify the specifics of innovative projects and develop a methodology for evaluating such projects and a means of information support for the evaluation process.

Against this backdrop, the purpose of this article is to develop a graphic model to assess the innovativeness, competitiveness, and eco-efficiency of eco-innovation projects. In the development of this method, a methodological approach was applied based on an assessment of the indicators of innovativeness, competitiveness, and eco-efficiency of eco-innovation projects.

Next, we provide the theoretical framework, followed by the results and conclusion.

\section{Theoretical framework}

Currently, the assessment of the environmental performance of a project is considered the most difficult aspect (Mutanov et al., 2018; Shvetsova et al., 2018). A project's compliance with environmental requirements as well as its innovativeness and competitiveness can only be determined if the method of its assessment considers several factors, including the following:

- $\quad$ Classification of the project according to the degree of environmental impact

- $\quad$ Coordination of the Terms of Reference (TOR) for assessment by appropriate criteria

- The implementation of basic requirements

- $\quad$ Control of accounting recommendations in the decisions made during the project

- Examination 


\section{ENTREPRENEURSHIP AND SUSTAINABILITY ISSUES}

ISSN 2345-0282 (online) http://jssidoi.org/jesi/

2019 Volume 6 Number 4 (June)

http://doi.org/10.9770/jesi.2019.6.4(41)

- The environmental conditions of the project

- The implementation of environmental conditions at the project implementation stage

The evaluation process accompanies each stage of the project cycle. The assessment results at every stage are presented to the investor, followed by a joint discussion of the environmental problems and the development of common approaches to solve the problems. The results of the assessment should be enough to determine the launch of the project.

Scarpellini, Valero-Gil, and Portillo-Tarragona (2016) noted that eco-innovation provides motivation for the move towards sustainable development. However, in many European Union member countries, eco-innovation projects are not particularly common due to significant barriers and a general lack of culture of incorporating ecoinnovation into organizational strategy in both government and corporate entities. Against the backdrop of this scenario, an analysis of the determinants of eco-innovation projects offers a new strategic approach to sustainable innovation initiative management. Important areas of evaluation are the innovativeness, competitiveness, and environmental attractiveness of the project. The most important criteria, which affect the associated project decisions, are elimination, prevention, reduction of environmental impact, and recycling of production and consumption byproducts (Table 1).

Table 1. Criteria for indicators of innovation and competitiveness of the innovation project

\begin{tabular}{|c|c|c|}
\hline & & Criteria for evaluating innovativeness \\
\hline \multirow{3}{*}{ APPLICABILITY } & 1.1 & Assessment of the importance of the project to the global economy \\
\hline & 1.2 & Assessment of the importance of the project to the national economy \\
\hline & 1.3 & $\begin{array}{l}\text { Conformity assessment of projects to commercialize the results of scientific and technical } \\
\text { activities with the trends and priorities relating to scientific and technical progress }\end{array}$ \\
\hline \multirow{3}{*}{$\begin{array}{c}\text { SCIENTIFIC AND } \\
\text { TECHNICAL } \\
\text { POTENTIAL }\end{array}$} & 2.1 & Degree of scientific and technical novelty of the project \\
\hline & 2.2 & Comparative assessment of the product (service) with existing counterparts in the market \\
\hline & 2.3 & Technological (technical) feasibility of activities intended to achieve the project goal \\
\hline \multirow{5}{*}{$\begin{array}{l}\text { MARKETING } \\
\text { RESEARCH }\end{array}$} & 3.1 & $\begin{array}{l}\text { Demand of business offered for commercialization of the results of scientific and } \\
\text { technical activities }\end{array}$ \\
\hline & 3.2 & Availability of potential consumers interested in the product / service \\
\hline & 3.3 & $\begin{array}{l}\text { Quality of development of the target market for product / service sales, as identified by } \\
\text { geographic, sectoral and other characteristics }\end{array}$ \\
\hline & 3.4 & $\begin{array}{l}\text { Availability of confirmed data regarding the market volume (within bot the Kazakhstan } \\
\text { and the global market) }\end{array}$ \\
\hline & 3.5 & Competitive advantages of products or services in comparison with existing analogues \\
\hline \multirow{3}{*}{$\begin{array}{c}\text { FINANCIAL } \\
\text { PLAN FOR THE } \\
\text { PROJECT }\end{array}$} & 4.1 & The reasonableness of the requested project funding \\
\hline & 4.2 & Cost estimates for project implementation \\
\hline & & $\begin{array}{l}\text { Criteria for evaluating competitiveness } \\
\end{array}$ \\
\hline \multirow{3}{*}{$\begin{array}{c}\text { READINESS FOR } \\
\text { COMMERCIALIZ } \\
\text { ATION }\end{array}$} & 1.1 & $\begin{array}{l}\text { Assessment of opportunities to achieve the goal of the commercialization of the results of } \\
\text { scientific and technical activities through planned activities }\end{array}$ \\
\hline & 1.2 & Adequacy of the team's competence to implement the project \\
\hline & 1.3 & $\begin{array}{l}\text { Evaluation of the material and technical base on which the project is planned to be } \\
\text { implemented }\end{array}$ \\
\hline \multirow{2}{*}{$\begin{array}{l}\text { EVALUATION OF } \\
\text { TECHNICAL AND } \\
\text { PRODUCTION } \\
\text { RISKS }\end{array}$} & 2.1 & $\begin{array}{l}\text { Technical risks associated with the implementation of technical / technological solutions, } \\
\text { including technical implementation being impossible }\end{array}$ \\
\hline & 2.2 & $\begin{array}{l}\text { Production risks associated with the organization of production, including a lack of the } \\
\text { necessary raw material base and the identification of environmental problems }\end{array}$ \\
\hline \multirow{4}{*}{$\begin{array}{c}\text { ECONOMIC } \\
\text { INDICATORS OF } \\
\text { THE PROJECT }\end{array}$} & 3.1 & Evaluation of the project's business model \\
\hline & 3.2 & $\begin{array}{l}\text { The validity of the economic indicators presented, including reasonable cost and sales } \\
\text { prices of the proposed product / service }\end{array}$ \\
\hline & 3.3 & The reasonableness of attracting the estimated number of team members \\
\hline & 3.4 & Availability of raw materials, materials, etc. \\
\hline
\end{tabular}




\begin{tabular}{|c|c|c|}
\hline \multirow[t]{2}{*}{$\begin{array}{c}\text { AVAILABILITY } \\
\text { OF CO- } \\
\text { FINANCING } \\
\end{array}$} & 4.1 & $\begin{array}{l}\text { Availability of co-financing (for every } 3 \% \text { co-financing, } 1 \text { point is awarded with a } \\
\text { maximum score of 9) }\end{array}$ \\
\hline & \multicolumn{2}{|r|}{ Criterion for assessing eco-efficiency } \\
\hline \multirow{4}{*}{$\begin{array}{c}\text { SCALE OF } \\
\text { ENVIRONMENTA } \\
\text { L IMPACT }\end{array}$} & 1.1 & National: covers the economic regions or territory of several regions \\
\hline & 1.2 & Regional: large city, region \\
\hline & 1.3 & Local: district, village, rural district \\
\hline & 1.4 & Local: industrial zone of the enterprise \\
\hline \multirow{4}{*}{ IMPACT OBJECT } & 2.1 & $\begin{array}{l}\text { Public safety: long-term pollution of the environment, causing statistically recorded } \\
\text { indicators of deterioration in the health of the population, threat to livelihoods }\end{array}$ \\
\hline & 2.2 & $\begin{array}{l}\text { Public health: environmental pollution which may lead to a deterioration in the health of } \\
\text { the population }\end{array}$ \\
\hline & 2.3 & Individual natural components: water bodies, atmospheric air, soils, forests, etc. \\
\hline & 2.4 & Natural resources: minerals, underground and surface waters, flora and fauna \\
\hline \multirow{3}{*}{$\begin{array}{c}\text { ENVIRONMENTA } \\
\text { L SITUATION IN } \\
\text { THE PROJECT } \\
\text { AREA }\end{array}$} & 3.1 & $\begin{array}{l}\text { Extremely unfavourable: according to long-term observations, the state of the } \\
\text { environment is assessed by environmental authorities as extreme }\end{array}$ \\
\hline & 3.2 & $\begin{array}{l}\text { Unfavourable: indicators of the state of the environment or its individual components } \\
\text { frequently exceed the maximum permissible values }\end{array}$ \\
\hline & 3.3 & Generally favourable, but there are separate sources of pollution \\
\hline \multirow{6}{*}{$\begin{array}{c}\text { TYPE OF } \\
\text { PREVENTABLE } \\
\text { ENVIRONMENTA } \\
\text { L IMPACT }\end{array}$} & 4.1 & Surface water pollution \\
\hline & 4.2 & Groundwater pollution \\
\hline & 4.3 & Air pollution \\
\hline & 4.4 & Pollution by hazardous industrial waste \\
\hline & 4.5 & Soil pollution \\
\hline & 4.6 & Noise, vibration, odours \\
\hline
\end{tabular}

\section{Graphic model for evaluating the innovativeness and competitiveness of innovative projects}

From the perspective of the market, innovative projects involve three interacting segments: science, business, and nature:

$$
K=f(I, L)
$$

where $I$ is the indicator of innovativeness, $K$ is the indicator of competitiveness, and $L$ is the indicator of ecoefficiency.

As shown in Figure 1, the evaluation of an innovation project through a graphic model to assess the innovativeness and competitiveness of a project occurs in three stages: 

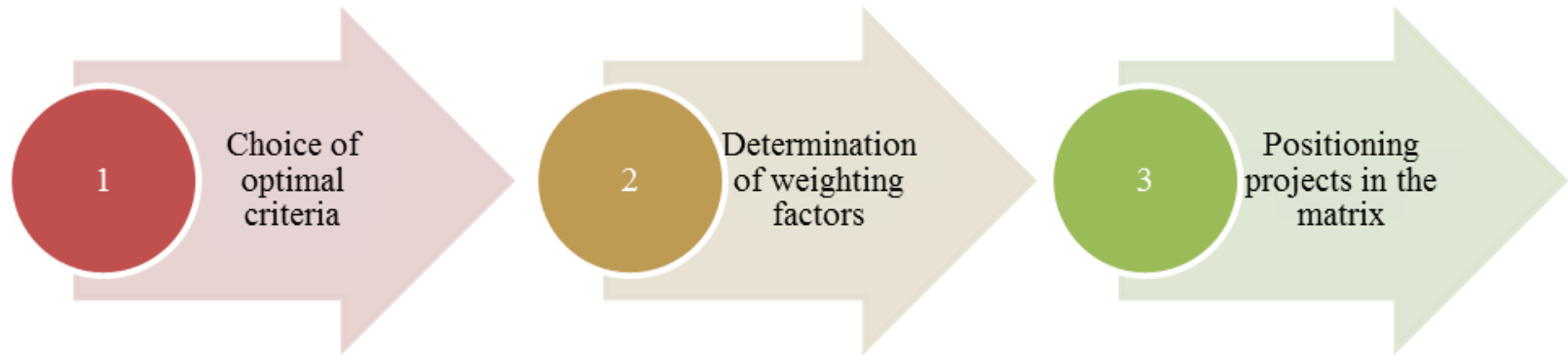

Fig. 1. The stages of evaluating innovativeness, competitiveness and eco-efficiency of an eco-innovative project Source: modified by authors from Mutanov, 2015

These values are determined by calculating the average values of expert estimates of each criterion. Possible criteria are presented in Table 1.

These values are determined by calculating the average values of expert estimates of each indicator, which, according to Mutanov (2015), are determined by the following formulas:

$$
\begin{aligned}
& I_{j}=\sum_{i=1}^{n} x_{i} f_{i j}, \sum_{i=1}^{n} x_{i}=1, \\
& K_{j}=\sum_{k=1}^{m} y_{k} g_{k j}, \sum_{k=1}^{m} y_{k}=1, \\
& L_{j}=\sum_{z=1}^{p} z_{l} h_{l j}, \sum_{l=1}^{p} z_{l}=1, \\
& I_{\min } \leq I_{j} \leq I_{\max }, K_{\min } \leq K_{j} \leq K_{\max }, L_{\min } \leq L_{j} \leq L_{\max }
\end{aligned}
$$

where $f_{i j}$ is the value of the $i$-th criterion of the $j$-th object (project) for the innovativeness indicator;

$x_{i}$ is the weighting coefficient of the $i$-th criterion for the innovativeness indicator;

$n$ is the number of criteria for the innovativeness indicator;

$g_{k j}$ is the value of the $k$-th criterion of the $j$-th object (project) for the competitiveness indicator;

$y_{k}$ is the weighting coefficient of the $k$-th factor for the competitiveness indicator;

$m$ is the number of criteria for the competitiveness indicator;

$h_{l j}$ is the value of the $l$-th criterion of the $j$-th object (project) for the eco-efficiency indicator;

$z_{l}$ is the weighting coefficient of the $l$-th factor for the eco-efficiency indicator;

$p$ is the number of criteria for the eco-efficiency indicator;

$j=\overline{1, J}$ with $/$ being the number of objects (projects); and

$I_{\min }, I_{\max }, K_{\min }, K_{\max }, L_{\min }, L_{\max }$ are the minimum and maximum values of the innovativeness, competitiveness, and eco-efficiency indicators, respectively (Mutanov, 2015).

Thus, it is necessary to determine the value of indicators $I$ and $K$, provided that each criterion is assigned an expert weighting factor and a value between 1 and 9 (Table 2). 
Table 2. System of expert assessments of the innovative project

\begin{tabular}{l|c|c|l}
\hline Threshold & Score & Evaluation Ratings & \multicolumn{1}{|c}{$\begin{array}{c}\text { Description of assessments, indicating strengths and } \\
\text { weaknesses }\end{array}$} \\
\hline \multirow{2}{*}{ High } & 9 & Exclusively & With exceptionally strong points without weaknesses \\
\cline { 2 - 4 } & 8 & Outstanding & With strengths and with insignificant weaknesses \\
\cline { 2 - 4 } & 7 & Fine & With strengths and with some minor weaknesses \\
\hline \multirow{2}{*}{ Average } & 6 & Very good & With strengths and with numerous minor weaknesses \\
\cline { 2 - 4 } & 5 & Good & With some strengths and moderate weaknesses \\
\cline { 2 - 4 } & 4 & Satisfactorily & With some strengths, but with one significant weakness \\
\hline \multirow{2}{*}{ Low } & 3 & Weakly & With minor strengths and multiple weaknesses. \\
\cline { 2 - 4 } & 2 & Unsatisfactory & Without strengths and significant weaknesses \\
\cline { 2 - 4 } & 1 & Extreme & Weaknesses without strengths \\
\hline
\end{tabular}

In order to adequately assess the significance of each criterion when determining the overall indicator, it is more rational to use weights and to apply a ranking method of calculation.

According to Mutanov (2015),

$$
R_{j}=\sum_{k=1}^{M} R_{j k}
$$

where $R_{j}$ is the sum of the ranks converted across all the experts for the $j$-th factor, $R_{j k}$ is the converted rank assigned by the $k$-th expert to the $j$-th factor, and $M$ is the number of experts.

Next, the weights of the various criteria are calculated, according to Mutanov (2015):

$$
W_{J}=R_{J} / \sum_{J=1}^{N} R_{J}
$$

where $W_{J}$ is the average weight of the criterion across all the experts; $N$ is the number of criteria.

An important component of the graphic model in assessing the innovativeness and competitiveness of a project is the judgment matrix, in which the values of the elements are not based on accurate measurements but rather on subjective judgments (these matrices are prepared by experts). The matrix of judgments is:

$$
A=\left(a_{i j}\right), i, j=1,2, \ldots J
$$

where $a_{i j}$ is the number corresponding to the significance of the object (criteria $I$ and $K$ ).

The "quality" of the expert filling in the judgment matrix is determined through the consistency relationship (OS). Values of $O S \leq 0.1$ are considered acceptable. For judgment matrix $A$, one must find the maximum eigenvalue $\lambda_{\max }$ and the vector of eigenvalues $Z$, i.e., it is necessary to solve the following equation:

$$
A \times Z=Z-\lambda_{\max }
$$

The components of the vector $Z$ are weight coefficients. 
The consistency of the expert estimates according to the criteria was verified by calculating the coefficients of the variation of the factors, which are analogues of the variance:

$$
S_{i}=\frac{m}{m-1} \times \frac{\left(\sum_{j=1}^{n} f_{i j}\right)^{2}-\Sigma_{j=1}^{n} f_{i j}^{2}}{\left(\Sigma_{j=1}^{n} f_{i j}\right)^{2}},
$$

where $S_{i}$ is the factor variation coefficient; $f_{i j}$ is the average value of the total number of $f_{i j}$ ranks of the $i$-th factor, as assigned by the $j$-th expert; $m$ is the number of experts; and $n$ is the number of criteria.

Since in our case experts are represented by various structures, it is necessary to control their homogeneity. To solve this problem, according to the estimates of various criteria received from experts, a concordance is defined: the consistency of their opinions. The coefficient of concordance $W$ was calculated using the formula Kendall proposed:

$$
W=\frac{12 \times S}{m^{2} \times\left(n^{s}-n\right)},
$$

where $S$ is the sum of squared differences (deviations), $m$ is the number of experts, and $n$ is the number of criteria.

The significance of the $W$ coefficients was verified for a confidence level of 0.01 (99\%) using the $\chi^{2}$ criterion, which minimizes the second kind of error (accepting the wrong hypothesis), at the $\alpha$ significance level—the probability of rejecting a valid hypothesis (the first kind of error), and the number of degrees of freedom $f$.

The value of the $\chi^{2}$ statistics can be calculated |via the formula:

$$
\chi^{2}=m \times f \times W
$$

where $m$ is the number of experts, $f$ is the number of degrees of freedom $f=k-1$, and $W$ is the coefficient of concordance.

The next stage of selection is the positioning of innovative projects based on the resulting graphic model.

\section{Research methodology}

As this is a preliminary study, the aim of the literature analysis was to identify the main factors affecting environmental change and eco-innovation in the environmental sector for 110 years (1901-2011). In this paper, (computer) content analysis was used as an analytical method for a longitudinal and systematic study of secondary sources of information (Stone et al., 1966; Woodrum, 1984; Bringer et al., 2006). More information about the method used in this article can be found in Montalvo, Diaz-Lopez, and Brandez (2011).

This study uses a thematic approach to better understand the role of ISC in environmental building design projects. Ketokivi and Choi (2014) discuss three different methodological approaches to the study of specific cases: the creation of a theory, the verification of the theory, and theory development. Theory development is not aimed at creating new theories or testing existing theories. This approach can be used to introduce new concepts, study boundary conditions, or study relationships between concepts. Unlike theoretical testing studies, this study 
did not expect empirical results from a priori formulations of judgments (see Ketokivi and Choi, 2014). Therefore, the design of the study is in better agreement with the inductive than with the deductive approach. This study aims to develop a theory by analyzing empirical data collected using a multiple case study approach (Yin et al., 2014). Although multiple cases are used, the goal is not to compare individual cases. These cases are used to explore and describe the role of ISC in projects. The study was conducted on the basis of expert assessments and investigated two projects implemented in Kazakhstan by time experts. The experts assessed a total of 40 indicators, each of which received a score ranging from 1 to 9 points, in three criteria categories.

\section{Results}

As an example, two projects that experts evaluated according to the criteria of innovation, competitiveness, and eco-efficiency were examined. The averages of each expert estimate of the indicators of innovation, competitiveness, and eco-efficiency are presented in Tables 3, 4, and 5.

Table 3. Average estimates of the criteria for evaluating innovativeness

\begin{tabular}{|c|c|c|c|c|c|c|c|c|}
\hline & & $\begin{array}{l}\text { Criteria for evaluating } \\
\text { innovativeness }\end{array}$ & $\begin{array}{l}\text { Project } \\
\text { №1 }\end{array}$ & $\begin{array}{l}\text { Project } \\
\text { №2 }\end{array}$ & $\begin{array}{l}\text { Project } \\
\text { №1 }\end{array}$ & $\begin{array}{l}\text { Project } \\
\text { №2 }\end{array}$ & $\begin{array}{l}\text { Project } \\
\text { №1 }\end{array}$ & $\begin{array}{l}\text { Project } \\
\text { №2 }\end{array}$ \\
\hline & & & \multicolumn{2}{|c|}{$\mathbf{1}^{\text {st }}$ expert } & \multicolumn{2}{|c|}{$2^{\text {nd }}$ expert } & \multicolumn{2}{|c|}{$3^{\text {rd }}$ expert } \\
\hline \multirow[b]{3}{*}{$\begin{array}{c}\text { APPLICABILI } \\
\text { TY }\end{array}$} & 1.1 & $\begin{array}{l}\text { Assessment of the importance } \\
\text { of the project to the global } \\
\text { economy }\end{array}$ & 3 & 5 & 2 & 6 & 3 & 8 \\
\hline & 1.2 & $\begin{array}{l}\text { Assessment of the importance } \\
\text { of the project to the national } \\
\text { economy }\end{array}$ & 5 & 9 & 4 & 9 & 4 & 9 \\
\hline & 1.3 & $\begin{array}{l}\text { Conformity assessment of } \\
\text { projects commercializing the } \\
\text { results of scientific and } \\
\text { technical activities with the } \\
\text { trends and priorities of } \\
\text { scientific and technical } \\
\text { progress }\end{array}$ & 4 & 8 & 3 & 8 & 2 & 9 \\
\hline \multirow{3}{*}{$\begin{array}{l}\text { SCIENTIFIC } \\
\text { AND } \\
\text { TECHNICAL } \\
\text { POTENTIAL }\end{array}$} & 2.1 & $\begin{array}{l}\text { Degree of scientific and } \\
\text { technical novelty of the } \\
\text { project }\end{array}$ & 4 & 8 & 3 & 7 & 4 & 8 \\
\hline & 2.2 & $\begin{array}{l}\text { Comparative assessment of } \\
\text { the product (service) with } \\
\text { existing counterparts in the } \\
\text { market }\end{array}$ & 3 & 7 & 4 & 8 & 4 & 7 \\
\hline & 2.3 & $\begin{array}{l}\text { Technological (technical) } \\
\text { feasibility of activities to } \\
\text { achieve the project goal }\end{array}$ & 7 & 9 & 6 & 8 & 6 & 9 \\
\hline \multirow{4}{*}{$\begin{array}{l}\text { MARKETING } \\
\text { RESEARCH }\end{array}$} & 3.1 & $\begin{array}{l}\text { Demand of business offered } \\
\text { for commercialization of the } \\
\text { results of scientific and } \\
\text { technical activities }\end{array}$ & 4 & 7 & 3 & 8 & 4 & 7 \\
\hline & 3.2 & $\begin{array}{l}\text { Availability of potential } \\
\text { consumers interested in the } \\
\text { product / service }\end{array}$ & 5 & 9 & 6 & 8 & 6 & 9 \\
\hline & 3.3 & $\begin{array}{l}\text { Quality of the development of } \\
\text { the target market for product / } \\
\text { service sales, as identified by } \\
\text { geographic, sectoral and other } \\
\text { characteristics }\end{array}$ & 5 & 6 & 6 & 5 & 7 & 8 \\
\hline & 3.4 & $\begin{array}{l}\text { Availability of confirmed } \\
\text { data about the market volume }\end{array}$ & 5 & 6 & 7 & 6 & 6 & 6 \\
\hline
\end{tabular}




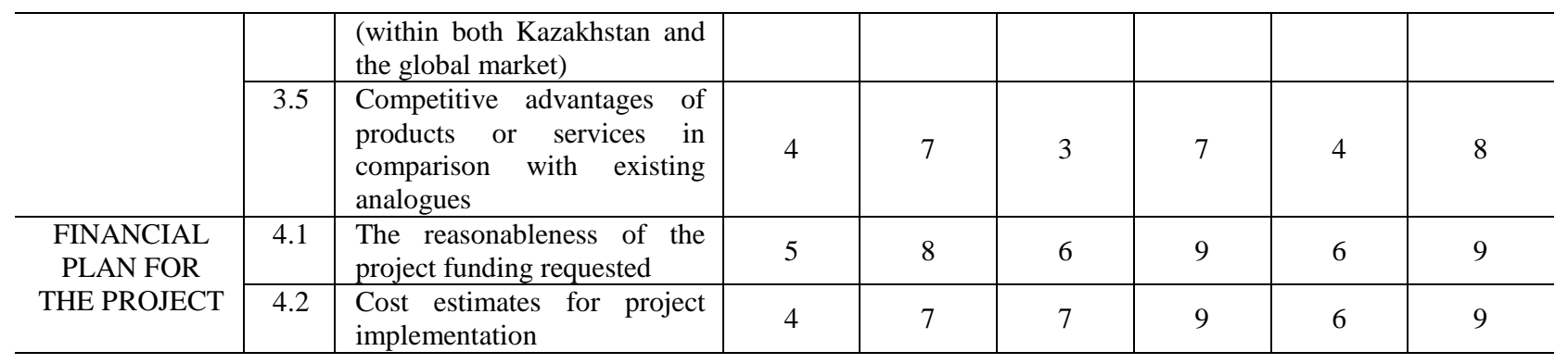

Table 4. Average estimates of the criteria for evaluating competitiveness

\begin{tabular}{|c|c|c|c|c|c|c|c|c|}
\hline & \multicolumn{2}{|r|}{$\begin{array}{c}\text { Criteria for evaluating } \\
\text { competitiveness }\end{array}$} & $\begin{array}{c}\text { Project } \\
\text { №1 } \\
\end{array}$ & $\begin{array}{c}\text { Project } \\
\text { №2 }\end{array}$ & $\begin{array}{c}\text { Project } \\
\text { №1 }\end{array}$ & $\begin{array}{c}\text { Project } \\
\text { №22 } \\
\end{array}$ & $\begin{array}{c}\text { Project } \\
\text { №1 } \\
\end{array}$ & $\begin{array}{c}\text { Project } \\
\text { №2 } \\
\end{array}$ \\
\hline & & & \multicolumn{2}{|c|}{$1^{\text {st }}$ expert } & \multicolumn{2}{|c|}{$2^{\text {nd }}$ expert } & \multicolumn{2}{|c|}{$3^{\text {rd }}$ expert } \\
\hline \multirow[t]{3}{*}{$\begin{array}{l}\text { READINESS } \\
\text { FOR } \\
\text { COMMERCIA } \\
\text { LIZATION }\end{array}$} & 1.1 & $\begin{array}{l}\text { Assessment of opportunities } \\
\text { to achieve the goal of } \\
\text { commercialization of the } \\
\text { results of scientific and } \\
\text { technical activities through } \\
\text { planned activities }\end{array}$ & 3 & 8 & 4 & 8 & 3 & 7 \\
\hline & 1.2 & $\begin{array}{l}\text { Sufficiency of the team's } \\
\text { competence to implement the } \\
\text { project }\end{array}$ & 7 & 8 & 6 & 8 & 6 & 8 \\
\hline & 1.3 & $\begin{array}{l}\text { Evaluation of the material and } \\
\text { technical base on which the } \\
\text { project will be implemented }\end{array}$ & 7 & 8 & 7 & 8 & 6 & 8 \\
\hline \multirow[t]{2}{*}{$\begin{array}{c}\text { EVALUATION } \\
\text { OF } \\
\text { TECHNICAL } \\
\text { AND } \\
\text { PRODUCTION } \\
\text { RISKS }\end{array}$} & 2.1 & $\begin{array}{l}\text { Technical risks associated } \\
\text { with the implementation of } \\
\text { technical / technological } \\
\text { solutions, including technical } \\
\text { implementation being } \\
\text { impossible }\end{array}$ & 8 & 4 & 8 & 3 & 8 & 3 \\
\hline & 2.2 & $\begin{array}{l}\text { Production risks associated } \\
\text { with the organization of } \\
\text { production, including a lack } \\
\text { of the necessary raw material } \\
\text { base, and the identification of } \\
\text { environmental problems }\end{array}$ & 5 & 3 & 4 & 2 & 4 & 2 \\
\hline \multirow{4}{*}{$\begin{array}{c}\text { ECONOMIC } \\
\text { INDICATORS } \\
\text { OF THE } \\
\text { PROJECT }\end{array}$} & 3.1 & $\begin{array}{l}\text { Evaluation of the project } \\
\text { business model }\end{array}$ & 6 & 8 & 7 & 8 & 7 & 8 \\
\hline & 3.2 & $\begin{array}{l}\text { The validity of the economic } \\
\text { indicators presented, } \\
\text { including the reasonableness } \\
\text { of the cost and sales price of } \\
\text { the proposed product / service }\end{array}$ & 6 & 8 & 7 & 8 & 7 & 8 \\
\hline & 3.3 & $\begin{array}{l}\text { The reasonableness of } \\
\text { attracting the estimated } \\
\text { number of team members }\end{array}$ & 7 & 8 & 8 & 8 & 8 & 9 \\
\hline & 3.4 & $\begin{array}{l}\text { Availability of raw materials, } \\
\text { materials, etc. }\end{array}$ & 7 & 8 & 8 & 8 & 8 & 8 \\
\hline \multirow{2}{*}{$\begin{array}{l}\text { AVAILABILIT } \\
\text { Y OF CO- } \\
\text { FINANCING }\end{array}$} & \multirow[t]{2}{*}{4.1} & \multirow{2}{*}{$\begin{array}{l}\text { Availability of co-financing } \\
\text { (for every } 3 \% \text { co-financing, } 1 \\
\text { point is awarded with a } \\
\text { maximum score of 9) }\end{array}$} & & & & & & \\
\hline & & & 2 & 4 & 2 & 4 & 2 & 4 \\
\hline
\end{tabular}


Table 5. Average estimates of the criteria for evaluating eco-efficiency

\begin{tabular}{|c|c|c|c|c|c|c|c|c|}
\hline & \multicolumn{2}{|r|}{$\begin{array}{c}\text { Criterion for assessing eco- } \\
\text { efficiency }\end{array}$} & $\begin{array}{l}\text { Project } \\
\text { №1 }\end{array}$ & $\begin{array}{l}\text { Project } \\
\text { №2 }\end{array}$ & $\begin{array}{l}\text { Project } \\
\text { №1 }\end{array}$ & $\begin{array}{l}\text { Project } \\
\text { №2 }\end{array}$ & $\begin{array}{l}\text { Project } \\
\text { №1 }\end{array}$ & $\begin{array}{l}\text { Project } \\
\text { №2 }\end{array}$ \\
\hline & & & \multicolumn{2}{|c|}{$1^{\text {st }}$ expert } & \multicolumn{2}{|c|}{$2^{\text {nd }}$ expert } & \multicolumn{2}{|c|}{$3^{\text {rd }}$ expert } \\
\hline \multirow{4}{*}{$\begin{array}{c}\text { SCALE OF } \\
\text { ENVIRONME } \\
\text { NTAL } \\
\text { IMPACT }\end{array}$} & 1.1 & $\begin{array}{l}\text { National: covers the } \\
\text { economic regions or territory } \\
\text { of several regions }\end{array}$ & 5 & 9 & 4 & 9 & 4 & 9 \\
\hline & 1.2 & Regional: large city, region & 3 & 7 & 2 & 7 & 2 & 7 \\
\hline & 1.3 & $\begin{array}{l}\text { Local: district, village, rural } \\
\text { district }\end{array}$ & 3 & 5 & 3 & 5 & 2 & 6 \\
\hline & 1.4 & $\begin{array}{l}\text { Local: industrial zone of the } \\
\text { enterprise }\end{array}$ & 1 & 2 & 1 & 1 & 1 & 3 \\
\hline \multirow{4}{*}{$\begin{array}{l}\text { IMPACT } \\
\text { OBJECT }\end{array}$} & 2.1 & $\begin{array}{l}\text { Public safety: long-term } \\
\text { pollution of the environment, } \\
\text { causing statistically recorded } \\
\text { indicators of deterioration in } \\
\text { the health of the population, } \\
\text { threat to livelihoods }\end{array}$ & 7 & 9 & 7 & 8 & 8 & 9 \\
\hline & 2.2 & $\begin{array}{l}\text { Public health: environmental } \\
\text { pollution, which may lead to } \\
\text { a deterioration in the health } \\
\text { of the population }\end{array}$ & 5 & 6 & 6 & 7 & 6 & 8 \\
\hline & 2.3 & $\begin{array}{lrr}\text { Individual } & & \text { natural } \\
\text { components: } & \text { water } & \text { bodies, } \\
\text { atmospheric } & \text { air, } & \text { soils, } \\
\text { forests, etc. } & & \\
\end{array}$ & 4 & 5 & 5 & 6 & 5 & 7 \\
\hline & 2.4 & $\begin{array}{l}\text { Natural resources: minerals, } \\
\text { underground and surface } \\
\text { waters, flora and fauna }\end{array}$ & 2 & 3 & 2 & 4 & 2 & 5 \\
\hline \multirow{3}{*}{$\begin{array}{l}\text { ENVIRONME } \\
\text { NTAL } \\
\text { SITUATION } \\
\text { IN THE } \\
\text { PROJECT } \\
\text { AREA }\end{array}$} & 3.1 & $\begin{array}{l}\text { Extremely unfavourable: } \\
\text { according to long-term } \\
\text { observations, the state of the } \\
\text { environment is assessed by } \\
\text { environmental authorities as } \\
\text { extreme }\end{array}$ & 7 & 9 & 6 & 8 & 7 & 8 \\
\hline & 3.2 & $\begin{array}{l}\text { Unfavourable: indicators of } \\
\text { the state of the environment } \\
\text { or its individual components } \\
\text { frequently exceed the } \\
\text { maximum permissible values }\end{array}$ & 4 & 5 & 5 & 6 & 5 & 6 \\
\hline & 3.3 & $\begin{array}{l}\text { Generally favourable, but } \\
\text { there are separate sources of } \\
\text { pollution }\end{array}$ & 1 & 2 & 2 & 2 & 1 & 2 \\
\hline \multirow{6}{*}{$\begin{array}{c}\text { TYPE OF } \\
\text { PREVENTABL } \\
\text { E } \\
\text { ENVIRONME } \\
\text { NTAL } \\
\text { IMPACT }\end{array}$} & 4.1 & Surface water pollution & 5 & 6 & 4 & 7 & 5 & 7 \\
\hline & 4.2 & Groundwater pollution & 5 & 6 & 4 & 7 & 5 & 6 \\
\hline & 4.3 & Air pollution & 7 & 9 & 7 & 9 & 8 & 9 \\
\hline & 4.4 & $\begin{array}{l}\text { Pollution by hazardous } \\
\text { industrial waste }\end{array}$ & 5 & 6 & 4 & 7 & 4 & 6 \\
\hline & 4.5 & Soil pollution & 2 & 3 & 2 & 4 & 2 & 3 \\
\hline & 4.6 & Noise, vibration, odours & 1 & 1 & 1 & 2 & 2 & 2 \\
\hline
\end{tabular}


The experts assessed the significance of the parameters by assigning them a rank number. The factor to which the expert gave the highest score was assigned rank 1. If the expert recognized several factors as equivalent, they were assigned the same rank number. Based on the data obtained from the questionnaire survey, a summary matrix of ranks was compiled. Since there are related ranks in the matrix (the same rank number) in the assessments of the first expert and since there are also related ranks in the assessments of the second and third experts, we will reform them. The reformation of ranks must be carried out without changing the experts' opinions; that is, the corresponding ratios between the ranking numbers must be preserved (more, less, or equal). Putting a rank above 1 or below the number of parameters is also not recommended.

Table 6. Rank matrix of the criteria for evaluating innovativeness

\begin{tabular}{|c|c|c|c|c|c|c|c|c|c|c|c|c|c|}
\hline $\begin{array}{l}\text { Indicators } \\
\text { / Experts }\end{array}$ & 1 & 2 & 3 & $\begin{array}{c}\text { Sum } \\
\text { of } \\
\text { ranks }\end{array}$ & $S_{\mathrm{i}}$ & $S_{i}^{2}$ & $\begin{array}{c}\text { Indicators } \\
\text { /Experts }\end{array}$ & 1 & 2 & 3 & $\begin{array}{c}\text { Sum } \\
\text { of } \\
\text { ranks }\end{array}$ & $S_{\mathrm{i}}$ & $S_{i}^{2}$ \\
\hline \multicolumn{7}{|c|}{ Project №1 } & \multicolumn{7}{|c|}{ Project №2 } \\
\hline $\mathrm{X} 1$ & 1.5 & 1 & 2 & 4.5 & -16.5 & 272.25 & $\mathrm{X} 1$ & 1 & 2.5 & 5.5 & 9 & -12 & 144 \\
\hline $\mathrm{X} 2$ & 10 & 6.5 & 5 & 21.5 & 0.5 & 0.25 & $\mathrm{X} 2$ & 12 & 12 & 10.5 & 34.5 & 13.5 & 182.25 \\
\hline $\mathrm{X} 3$ & 5 & 3.5 & 1 & 9.5 & -11.5 & 132.25 & $\mathrm{X} 3$ & 9 & 8 & 10.5 & 27.5 & 6.5 & 42.25 \\
\hline $\mathrm{X}_{4}$ & 5 & 3.5 & 5 & 13.5 & -7.5 & 56.25 & $\mathrm{X} 4$ & 9 & 4.5 & 5.5 & 19 & -2 & 4 \\
\hline $\mathrm{X}_{5}$ & 1.5 & 6.5 & 5 & 13 & -8 & 64 & $\mathrm{X} 5$ & 5.5 & 8 & 2.5 & 16 & -5 & 25 \\
\hline $\mathrm{X}_{6}$ & 13 & 9.5 & 10 & 32.5 & 11.5 & 132.25 & $\mathrm{X} 6$ & 12 & 8 & 10.5 & 30.5 & 9.5 & 90.25 \\
\hline $\mathrm{X} 7$ & 5 & 3.5 & 5 & 13.5 & -7.5 & 56.25 & $\mathrm{X} 7$ & 5.5 & 8 & 2.5 & 16 & -5 & 25 \\
\hline $\mathrm{X} 8$ & 10 & 9.5 & 10 & 29.5 & 8.5 & 72.25 & $\mathrm{X} 8$ & 12 & 8 & 10.5 & 30.5 & 9.5 & 90.25 \\
\hline $\mathrm{X} 9$ & 10 & 9.5 & 13 & 32.5 & 11.5 & 132.25 & $\mathrm{X} 9$ & 2.5 & 1 & 5.5 & 9 & -12 & 144 \\
\hline $\mathrm{X}_{10}$ & 10 & 12.5 & 10 & 32.5 & 11.5 & 132.25 & $\mathrm{X}_{10}$ & 2.5 & 2.5 & 1 & 6 & -15 & 225 \\
\hline $\mathrm{X}_{11}$ & 5 & 3.5 & 5 & 13.5 & -7.5 & 56.25 & $\mathrm{X}_{11}$ & 5.5 & 4.5 & 5.5 & 15.5 & -5.5 & 30.25 \\
\hline $\mathrm{X}_{12}$ & 10 & 9.5 & 10 & 29.5 & 8.5 & 72.25 & $\mathrm{X}_{12}$ & 9 & 12 & 10.5 & 31.5 & 10.5 & 110.25 \\
\hline $\mathrm{X}_{13}$ & 5 & 12.5 & 10 & 27.5 & 6.5 & 42.25 & $\mathrm{X}_{13}$ & 5.5 & 12 & 10.5 & 28 & 7 & 49 \\
\hline$\sum$ & 91 & 91 & 91 & 273 & & 1221 & $\sum$ & 91 & 91 & 91 & 273 & & 1161.5 \\
\hline
\end{tabular}


ENTREPRENEURSHIP AND SUSTAINABILITY ISSUES

ISSN 2345-0282 (online) http://jssidoi.org/jesi/

2019 Volume 6 Number 4 (June)

http://doi.org/10.9770/jesi.2019.6.4(41)

Table 7. Rank matrix of the criteria for evaluating competitiveness

\begin{tabular}{|c|c|c|c|c|c|c|c|c|c|c|c|c|c|}
\hline $\begin{array}{l}\text { Indicators } \\
\text { / Experts }\end{array}$ & 1 & 2 & 3 & $\begin{array}{c}\text { Sum } \\
\text { of } \\
\text { ranks }\end{array}$ & $s_{k}$ & $s_{k}^{2}$ & $\begin{array}{c}\text { Indicators } \\
\text { /Experts }\end{array}$ & 1 & 2 & 3 & $\begin{array}{c}\text { Sum } \\
\text { of } \\
\text { ranks }\end{array}$ & $S_{k}$ & $s_{k}^{2}$ \\
\hline \multicolumn{7}{|c|}{ Project №1 } & \multicolumn{7}{|c|}{ Project №2 } \\
\hline $\mathrm{y}_{1}$ & 2 & 2.5 & 2 & 6.5 & -10 & 100 & $\mathrm{y}_{1}$ & 7 & 7 & 4 & 18 & 1.5 & 2.25 \\
\hline $\mathrm{y}_{2}$ & 7.5 & 4 & 4.5 & 16 & -0.5 & 0.25 & $\mathrm{y}_{2}$ & 7 & 7 & 7 & 21 & 4.5 & 20.25 \\
\hline $\mathrm{y} 3$ & 7.5 & 6 & 4.5 & 18 & 1.5 & 2.25 & $\mathrm{y} 3$ & 7 & 7 & 7 & 21 & 4.5 & 20.25 \\
\hline $\mathrm{y} 4$ & 10 & 9 & 9 & 28 & 11.5 & 132.25 & $\mathrm{y} 4$ & 2.5 & 2 & 2 & 6.5 & -10 & 100 \\
\hline $\mathrm{y}_{5}$ & 3 & 2.5 & 3 & 8.5 & -8 & 64 & $\mathrm{y}_{5}$ & 1 & 1 & 1 & 3 & -13.5 & 182.25 \\
\hline y6 & 4.5 & 6 & 6.5 & 17 & 0.5 & 0.25 & y6 & 7 & 7 & 7 & 21 & 4.5 & 20.25 \\
\hline $\mathrm{y}_{7}$ & 4.5 & 6 & 6.5 & 17 & 0.5 & 0.25 & $\mathrm{y}_{7}$ & 7 & 7 & 7 & 21 & 4.5 & 20.25 \\
\hline $\mathrm{y}_{8}$ & 7.5 & 9 & 9 & 25.5 & 9 & 81 & $\mathrm{y}_{8}$ & 7 & 7 & 10 & 24 & 7.5 & 56.25 \\
\hline y9 & 7.5 & 9 & 9 & 25.5 & 9 & 81 & y9 & 7 & 7 & 7 & 21 & 4.5 & 20.25 \\
\hline $\mathrm{y} 10$ & 1 & 1 & 1 & 3 & -13.5 & 182.25 & $\mathrm{y} 10$ & 2.5 & 3 & 3 & 8.5 & -8 & 64 \\
\hline$\sum$ & 55 & 55 & 55 & 165 & & 643.5 & $\sum$ & 55 & 55 & 55 & 165 & & 506 \\
\hline
\end{tabular}

Table 8. Rank matrix of the criteria for evaluating eco-efficiency

\begin{tabular}{|c|c|c|c|c|c|c|c|c|c|c|c|c|c|}
\hline $\begin{array}{c}\text { Indica } \\
\text { tors / } \\
\text { Expert } \\
\mathrm{s}\end{array}$ & 1 & 2 & 3 & $\begin{array}{c}\text { Sum } \\
\text { of } \\
\text { ranks }\end{array}$ & $S_{\mathbb{1}}$ & $s_{l}^{2}$ & $\begin{array}{l}\text { Indicators } \\
\text { /Experts }\end{array}$ & 1 & 2 & 3 & $\begin{array}{c}\text { Sum } \\
\text { of } \\
\text { rank } \\
\text { s }\end{array}$ & $S_{1}$ & $S_{i}^{2}$ \\
\hline \multicolumn{7}{|c|}{ Project №1 } & \multicolumn{7}{|c|}{ Project №2 } \\
\hline $\mathrm{Z} 1$ & 12 & 9.5 & 8.5 & 30 & 3 & 9 & $\mathrm{Z}_{1}$ & 15.5 & 16.5 & 16 & 48 & 21 & 441 \\
\hline $\mathrm{Z}_{2}$ & 6.5 & 4.5 & 5 & 16 & -11 & 121 & $\mathrm{Z}_{2}$ & 13 & 11 & 11 & 35 & 8 & 64 \\
\hline $\mathrm{Z}_{3}$ & 6.5 & 7 & 5 & 18.5 & -8.5 & 72.25 & $\mathrm{Z}_{3}$ & 7 & 6 & 7.5 & 20.5 & -6.5 & 42.25 \\
\hline $\mathrm{Z}_{4}$ & 2 & 1.5 & 1.5 & 5 & -22 & 484 & $\mathrm{Z} 4$ & 2.5 & 1 & 3.5 & 7 & -20 & 400 \\
\hline $\mathrm{Z} 5$ & 16 & 16.5 & 16.5 & 49 & 22 & 484 & $\mathrm{Z} 5$ & 15.5 & 14.5 & 16 & 46 & 19 & 361 \\
\hline Z6 & 12 & 14.5 & 14 & 40.5 & 13.5 & 182.25 & Z6 & 10.5 & 11 & 13.5 & 35 & 8 & 64 \\
\hline $\mathrm{Z7}$ & 8.5 & 12.5 & 11.5 & 32.5 & 5.5 & 30.25 & $\mathrm{Z7}$ & 7 & 7.5 & 11 & 25.5 & -1.5 & 2.25 \\
\hline $\mathrm{Z} 8$ & 4.5 & 4.5 & 5 & 14 & -13 & 169 & $\mathrm{Z} 8$ & 4.5 & 4.5 & 5 & 14 & -13 & 169 \\
\hline $\mathrm{Z} 9$ & 16 & 14.5 & 15 & 45.5 & 18.5 & 342.25 & $\mathrm{Z} 9$ & 15.5 & 14.5 & 13.5 & 43.5 & 16.5 & 272.25 \\
\hline $\mathrm{Z}_{10}$ & 8.5 & 12.5 & 11.5 & 32.5 & 5.5 & 30.25 & $\mathrm{Z}_{10}$ & 7 & 7.5 & 7.5 & 22 & -5 & 25 \\
\hline $\mathrm{Z}_{11}$ & 2 & 4.5 & 1.5 & 8 & -19 & 361 & $\mathrm{Z}_{11}$ & 2.5 & 2.5 & 1.5 & 6.5 & -20.5 & 420.25 \\
\hline $\mathrm{Z} 12$ & 12 & 9.5 & 11.5 & 33 & 6 & 36 & $\mathrm{Z} 12$ & 10.5 & 11 & 11 & 32.5 & 5.5 & 30.25 \\
\hline $\mathrm{Z}_{13}$ & 12 & 9.5 & 11.5 & 33 & 6 & 36 & $\mathrm{Z}_{13}$ & 10.5 & 11 & 7.5 & 29 & 2 & 4 \\
\hline $\mathrm{Z}_{14}$ & 16 & 16.5 & 16.5 & 49 & 22 & 484 & $\mathrm{Z}_{14}$ & 15.5 & 16.5 & 16 & 48 & 21 & 441 \\
\hline $\mathrm{Z}_{15}$ & 12 & 9.5 & 8.5 & 30 & 3 & 9 & $\mathrm{Z}_{15}$ & 10.5 & 11 & 7.5 & 29 & 2 & 4 \\
\hline $\mathrm{Z}_{16}$ & 4.5 & 4.5 & 5 & 14 & -13 & 169 & $\mathrm{Z}_{16}$ & 4.5 & 4.5 & 3.5 & 12.5 & -14.5 & 210.25 \\
\hline $\mathrm{Z} 17$ & 2 & 1.5 & 5 & 8.5 & -18.5 & 342.25 & $\mathrm{Z} 17$ & 1 & 2.5 & 1.5 & 5 & -22 & 484 \\
\hline$\sum$ & 153 & 153 & 153 & 459 & & 3361.5 & $\sum$ & 153 & 153 & 153 & 459 & & 3434.5 \\
\hline
\end{tabular}


Therein,

$$
\begin{aligned}
& S_{i}=\sum x_{i j}-\frac{\sum \sum x_{i j}}{n}=\sum x_{i j}-21 \text { (Project №1, №2) } \\
& S_{k}=\sum y_{k j}-\frac{\sum \sum y_{k j}}{n}=\sum y_{k j}-16.5 \text { (Project №1, №2) } \\
& S_{k}=\sum z_{l j}-\frac{\sum \sum z_{i j}}{n}=\sum z_{l j}-27 \text { (Project №1, №2) }
\end{aligned}
$$

The correctness of the matrix on the basis of the checksum calculation is then verified:

$$
\begin{aligned}
& \sum x_{i j}=\frac{(1+n) n}{2}=\frac{(1+13) 13}{2}=91 \text { (Project №1, №2) } \\
& \sum y_{k j}=\frac{(1+n) n}{2}=\frac{(1+10) 10}{2}=55 \text { (Project №1, №2) } \\
& \sum z_{l j}=\frac{(1+n) n}{2}=\frac{(1+17) 17}{2}=153 \text { (Project №1, №2) }
\end{aligned}
$$

The sums of the columns of the matrix are equal to both each other and the checksum, which means that the matrix is composed correctly.

The assessment of the average degree of consistency of the opinions of all the experts is determined by the coefficient of concordance in the instance of related ranks (the same values of ranks in the assessments of one expert):

$$
W=\frac{s}{\frac{1}{12} \times m^{2}\left(n^{3}-n\right)-m \times \sum T_{i}},
$$

where $S_{i}=1221, \mathrm{n}=13, \mathrm{~m}=3$ (Project №1); $S_{i}=1161.5, \mathrm{n}=13, \mathrm{~m}=3$ (Project №2)

$$
\begin{aligned}
& S_{k}=645.5, \mathrm{n}=10, \mathrm{~m}=3 \text { (Project №1); } S_{k}=506, \mathrm{n}=13, \mathrm{~m}=3 \text { (Project №2) } \\
& S_{l}=3361.5, \mathrm{n}=17, \mathrm{~m}=3 \text { (Project №1); } S_{l}=3434.5, \mathrm{n}=17, \mathrm{~m}=3 \text { (Project №2) } \\
& T_{i}=\frac{1}{12} \sum\left(t_{w}^{3}-t_{w}\right),
\end{aligned}
$$

where $T_{i}$ is the number of bundles (types of repeating elements) in the estimates of the $i$-th expert and $t_{w}$ is the number of elements in the $l$-th bundle for the $i$-th expert (the number of repeating elements).

$\mathrm{T}_{1}=\left[\left(2^{3}-2\right)+\left(5^{3}-5\right)+\left(5^{3}-5\right)\right] / 12=20.5$

$\mathrm{T}_{2}=\left[\left(2^{3}-2\right)+\left(4^{3}-4\right)+\left(4^{3}-4\right)+\left(2^{3}-2\right)\right] / 12=11$

$\mathrm{T}_{3}=\left[\left(5^{3}-5\right)+\left(5^{3}-5\right)\right] / 12=20$

$\sum T_{i}=20.5+11+20=51.5$ (Project №1)

$W=\frac{1221}{\frac{1}{12} \times 3^{2}\left(13^{\mathrm{g}}-13\right)-3 \times 51_{1} 5}=0.82$ (Project №1) 
$\mathrm{T}_{1}=\left[\left(3^{3}-3\right)+\left(3^{3}-3\right)+\left(4^{3}-4\right)+\left(2^{3}-2\right)\right] / 12=9.5$

$\mathrm{T}_{2}=\left[\left(2^{3}-2\right)+\left(3^{3}-3\right)+\left(5^{3}-5\right)+\left(2^{3}-2\right)\right] / 12=13$

$\mathrm{T}_{3}=\left[\left(4^{3}-4\right)+\left(6^{3}-6\right)+\left(2^{3}-2\right)\right] / 12=23$

$\sum T_{i}=9.5+13+23=45.5$ (Project №2)

$$
\begin{aligned}
& W=\frac{1161,5}{\frac{1}{1 \mathrm{n}} \times 3^{2}\left(13^{\mathrm{g}}-13\right)-3 \times 45.5}=0,77 \text { (Project №2) } \\
& \mathrm{T}_{1}=\left[\left(4^{3}-4\right)+\left(2^{3}-2\right)\right] / 12=5.5 \\
& \mathrm{~T}_{2}=\left[\left(2^{3}-2\right)+\left(3^{3}-3\right)+\left(3^{3}-3\right)\right] / 12=4.5 \\
& \mathrm{~T}_{3}=\left[\left(2^{3}-2\right)+\left(3^{3}-3\right)+\left(2^{3}-2\right)\right] / 12=3 \\
& \sum T_{k}=5.5+4.5+3=13 \text { (Project №1) } \\
& W=\frac{6433_{n}^{5}}{\frac{1}{12} \times 3^{2}\left(10^{8}-10\right)-3 \times 13}=0.91 \text { (Project №1) } \\
& \mathrm{T}_{1}=\left[\left(7^{3}-7\right)+\left(2^{3}-2\right)\right] / 12=28.5 \\
& \mathrm{~T}_{2}=\left[\left(7^{3}-7\right)\right] / 12=28 \\
& \mathrm{~T}_{3}=\left[\left(5^{3}-5\right)\right] / 12=10 \\
& \sum T_{k}=28.5+28+10=66.5 \text { (Project №2) } \\
& W=\frac{506}{\frac{1}{12} \times 3^{2}\left(10^{8}-10\right)-3 \times 66.5}=0.93 \text { (Project №2) } \\
& \mathrm{T}_{1}=\left[\left(5^{3}-5\right)+\left(2^{3}-2\right)+\left(3^{3}-3\right)+\left(3^{3}-3\right)+\left(2^{3}-2\right)+\left(2^{3}-2\right)\right] / 12=15.5 \\
& \mathrm{~T}_{2}=\left[\left(4^{3}-4\right)+\left(4^{3}-4\right)+\left(2^{3}-2\right)+\left(2^{3}-2\right)+\left(2^{3}-2\right)+\left(2^{3}-2\right)\right] / 12=12 \\
& \mathrm{~T}_{3}=\left[\left(2^{3}-2\right)+\left(5^{3}-5\right)+\left(2^{3}-2\right)+\left(2^{3}-2\right)+\left(4^{3}-4\right)\right] / 12=16.5 \\
& \sum T_{l}=15.5+12+16.5=44 \text { (Project №1) } \\
& W=\frac{3361,5}{\frac{1}{12} \times 3^{2}\left(17^{8}-17\right)-3 \times 44}=0.95 \text { (Project №1) } \\
& \mathrm{T}_{1}=\left[\left(4^{3}-4\right)+\left(3^{3}-3\right)+\left(2^{3}-2\right)+\left(4^{3}-4\right)+\left(2^{3}-2\right)\right] / 12=13 \\
& \mathrm{~T}_{2}=\left[\left(2^{3}-2\right)+\left(5^{3}-5\right)+\left(2^{3}-2\right)+\left(2^{3}-2\right)+\left(2^{3}-2\right)+\left(2^{3}-2\right)\right] / 12=12.5 \\
& \mathrm{~T}_{3}=\left[\left(3^{3}-3\right)+\left(3^{3}-3\right)+\left(4^{3}-4\right)+\left(2^{3}-2\right)+\left(2^{3}-2\right)+\left(2^{3}-2\right)\right] / 12=10.5 \\
& \sum T_{l}=13+12.5+10.5=36 \text { (Project №2) }
\end{aligned}
$$

$W=\frac{3434,5}{\frac{1}{12} \times 3^{2}\left(17^{3}-17\right)-3 \times 36}=0.96$ (Project №2)

$\mathrm{W}=0.82 ; 0.77 ; 0.91 ; 0.93 ; 0.95 ; 0.96$ indicates a high degree of consistency of expert opinions. 
The significance of the coefficient of concordance is determined by calculating the Pearson matching criterion:

$$
\begin{aligned}
& \chi^{2}=\frac{S}{\frac{1}{12} \times m n(n+1)+\frac{1}{n-1} \times \sum T_{i}} \\
& \chi_{i}^{2}=\frac{1221}{\frac{1}{12} \times 3 \times 13(13+1)+\frac{1}{18-1} \times 51.5}=29.63 \text { (Project №1) } \\
& \chi_{i}^{2}=\frac{1161_{1} 5}{\frac{1}{12} \times 3 \times 13(13+1)+\frac{1}{18-1} \times 45.5}=27.85 \text { (Project №2) } \\
& \chi_{k}^{2}=\frac{643,5}{\frac{1}{12} \times 3 \times 10(10+1)+\frac{1}{10-1} \times 13}=24.7 \text { (Project №1) } \\
& \chi_{k}^{2}=\frac{506}{\frac{1}{12} \times 3 \times 10(10+1)+\frac{1}{10-1} \times 66.5}=25.16 \text { (Project №2) } \\
& \chi_{l}^{2}=\frac{3361_{s} 5}{\frac{1}{12} \times 3 \times 17(17+1)+\frac{1}{17-1} \times 44}=45.58 \text { (Project №1) } \\
& \chi_{l}^{2}=\frac{3434,5}{\frac{1}{12} \times 3 \times 17(17+1)+\frac{1}{17-1} \times 36}=46.26 \text { (Project №2) }
\end{aligned}
$$

The $\chi^{2}$ calculated is comparable to the table value for the number of degrees of freedom

$K=n-1=13-1=12 ; K=n-1=10-1=9 ; \quad K=n-1=17-1=16$ and at a given significance level $\alpha=0.01$. Since $\chi^{2}$ is a calculated $29.63 \geq$ tabular (26.21697), 27.85 $\geq$ tabular (26.21697), 24.7 $\geq$ tabular (21.66599), 25.16 $\geq$ tabular (21.66599), $45.58 \geq$ tabular (31.99993), 46.26 $\geq$ tabular (31.99993), then W $=0.82,0.77,0.91,0.93,0.95,0.96$ is not a random value, and therefore the results obtained make sense and can be used in further studies.

Based on the sum of the ranks (table), we can calculate the weights of the parameters considered. We transform the survey matrix into a matrix of transformed ranks using the formula $s_{i j}=x_{\max }-x_{i j} ; s_{k j}=y_{\max }-y_{k j}$; $s_{l j}=z_{\max }-z_{l j}$, where $x_{\max }=7$ (Project 1); $x_{\max }=9$ (Project 2); $y_{\max }=8$ (Project 1); $y_{\max }=9$ (Project 2); $z_{\max }=8$ (Project 1$) ; z_{\max }=9$ (Project 2$)$. 
Table 9. Average estimates of the criteria of innovation

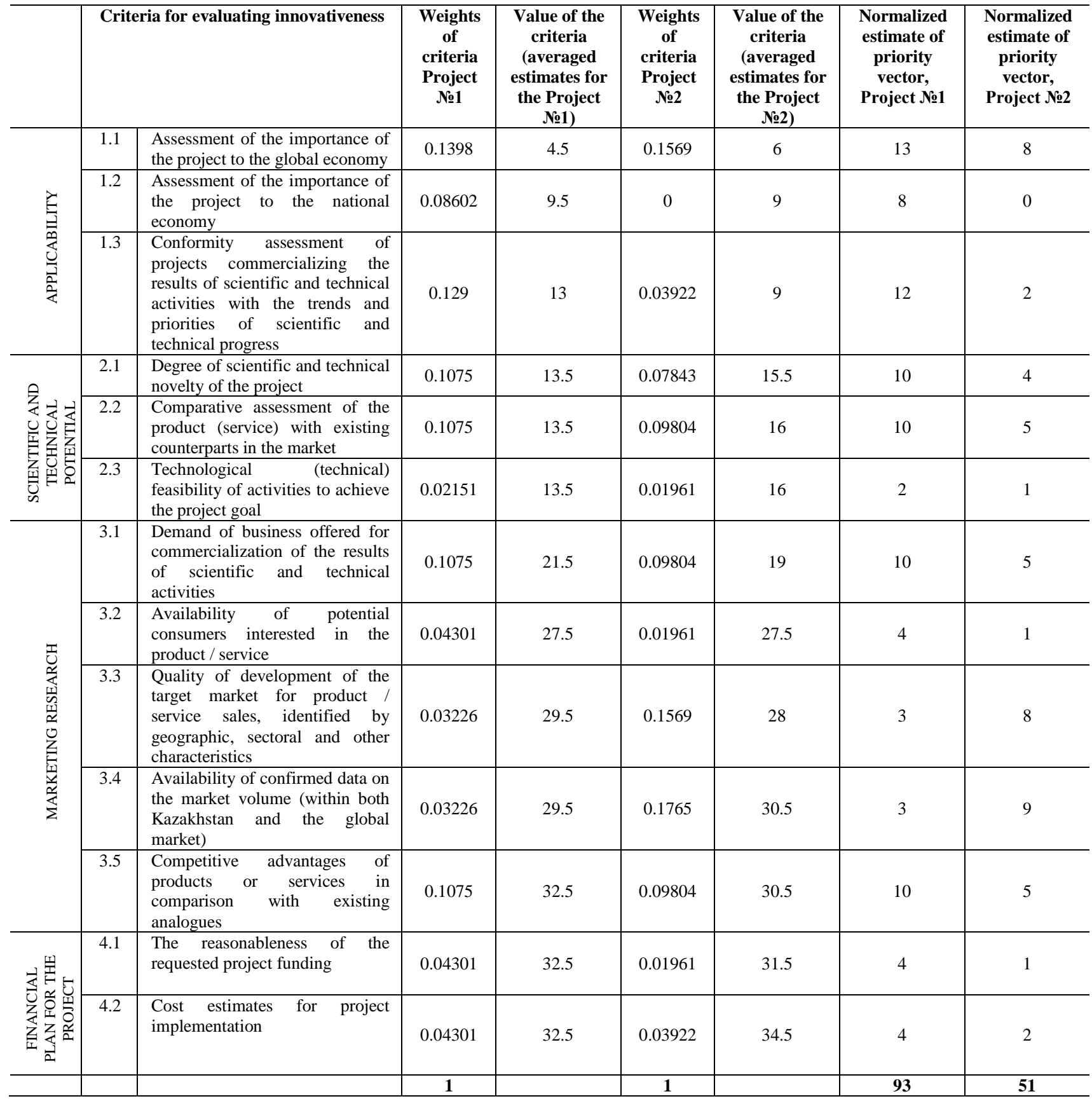


Table 10. Average estimates of the criteria of competitiveness

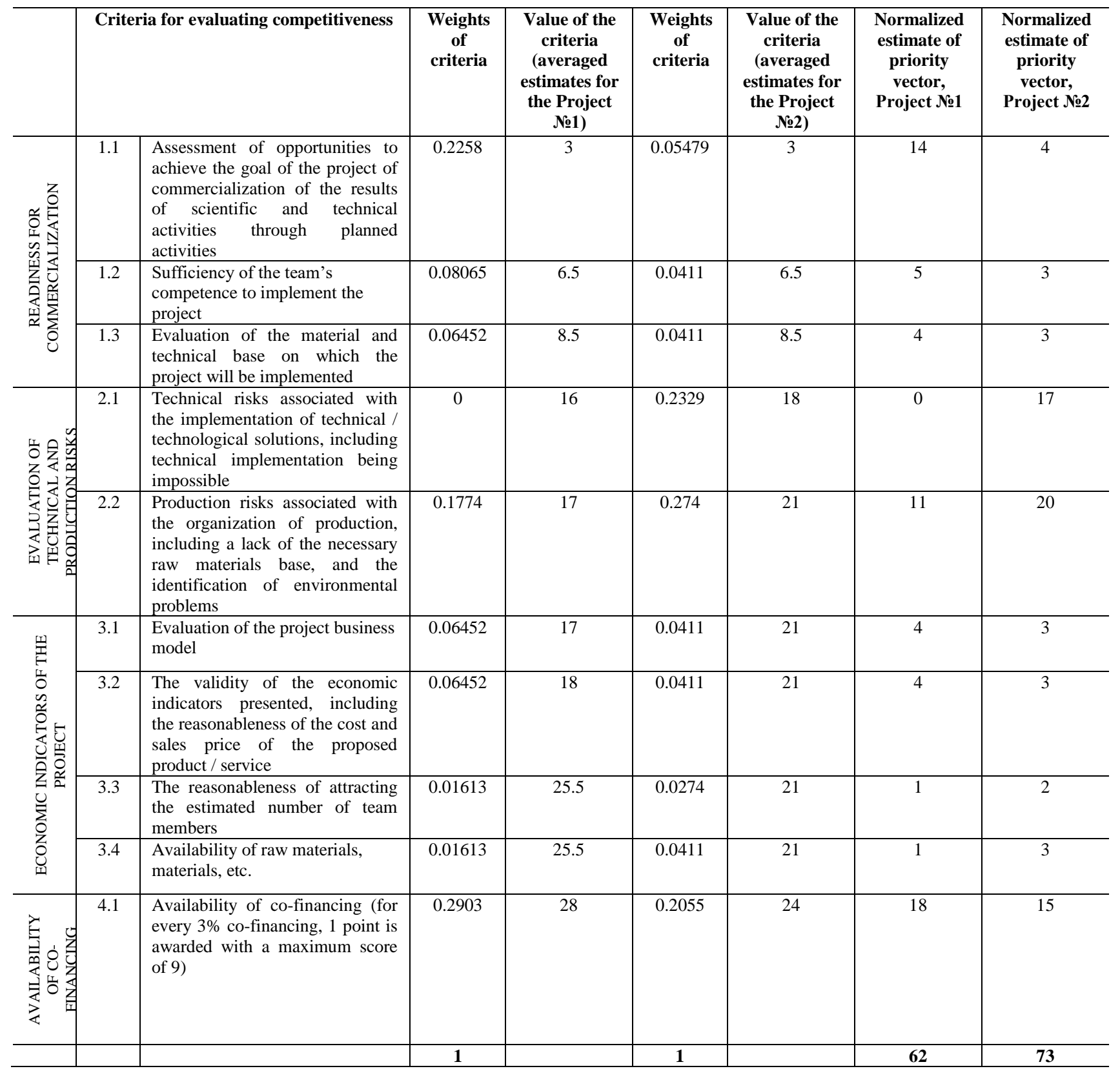


Table 11. Average estimates of the criteria of eco-efficiency

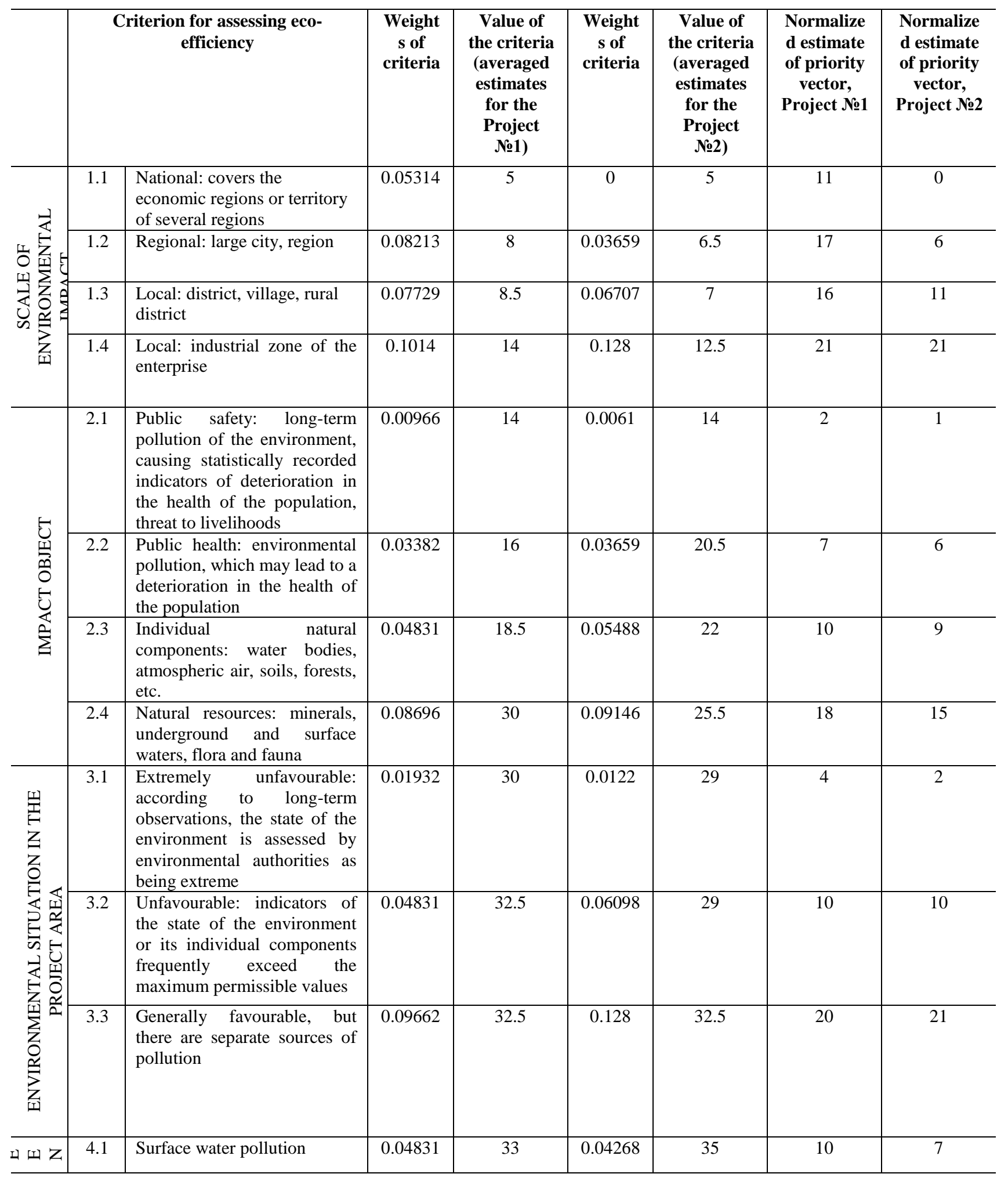


ENTREPRENEURSHIP AND SUSTAINABILITY ISSUES

ISSN 2345-0282 (online) http://jssidoi.org/jesi/

2019 Volume 6 Number 4 (June)

http://doi.org/10.9770/jesi.2019.6.4(41)

\begin{tabular}{c|c|l|c|c|c|c|c|c|c}
\hline & 4.2 & Groundwater pollution & 0.04831 & 33 & 0.04878 & 35 & 10 & 8 \\
\cline { 2 - 8 } & 4.3 & Air pollution & 0.00966 & 40.5 & 0 & 43.5 & 2 & 0 \\
\cline { 2 - 9 } & 4.4 & $\begin{array}{l}\text { Pollution by hazardous } \\
\text { industrial waste }\end{array}$ & 0.05314 & 45.5 & 0.04878 & 46 & 11 & 8 \\
\cline { 2 - 9 } & 4.5 & Soil pollution & 0.08696 & 49 & 0.1037 & 48 & 18 & 17 \\
\cline { 2 - 8 } & 4.6 & Noise, vibration, odours & 0.09662 & 49 & 0.1341 & 48 & $\mathbf{2 0 7}$ & $\mathbf{1 6 4}$ \\
\hline
\end{tabular}

\section{Conclusion}

The article investigated the fundamental work of eminent scientists (López and Montalvo, 2015; Levidow et al., 2016; Lambrechts et al., 2019) regarding the methodology and methods used to evaluate innovative and ecoinnovative projects and described the shortcomings of the existing guidelines in the literature and applied by the industry. The article presents a method by which to assess the feasibility and economic and environmental performance of eco-innovative projects. This model facilitates a comprehensive project assessment based on absolute positioning. The requirements for the assessment and the selection models of eco-innovation projects and the tasks in the field of their modernization are formulated in order to adapt to the world and modern economic relations. For example, they consider the following:

- The need to build a hierarchical system of indicators corresponding to the levels of eco-innovation project management

- $\quad$ The need to consider the various contributions of indicators of different hierarchical levels (qualitative and quantitative) to the total integrated indicator of an eco-innovation project

- The impossibility of making an unambiguous assignment of a number of indicators to a particular class

Taking into account the stated requirements, the methodological guidelines have been developed to solve the problems associated with evaluating the effectiveness of investing in eco-innovative projects during competitive selection.

An appropriate decision-support system provides a program-target approach using comprehensive experience in assessing eco-innovation projects in terms of such parameters as innovation, competitiveness, and eco-efficiency. This decision-support system is designed for use by the expert commissions responsible for venture capital funds, development institutions, and other potential investors who need to select appropriate eco-innovation projects.

Competition among companies in a market economy generally takes the form of project competition, and the ability of a company to compete directly in a specific project market depends on the competitiveness of its project innovation. Modeling methods are based on the judgment that an assessment of the competitiveness of an economic entity can be made by assessing the competitiveness of its eco-projects: the greater the competitiveness of such projects, the greater the competitiveness of the enterprise. Various methods can be used to find this ratio. A brief description of the most common is given below:

- The undoubted advantages of this approach include the fact that it considers one of the most important components of an enterprise's competitiveness: the competitiveness of its eco-innovative projects. Indeed, it is difficult to imagine a successful enterprise that does not have a portfolio of competitive innovative projects. 


\section{ENTREPRENEURSHIP AND SUSTAINABILITY ISSUES}

ISSN 2345-0282 (online) http://jssidoi.org/jesi/

2019 Volume 6 Number 4 (June)

http://doi.org/10.9770/jesi.2019.6.4(41)

- A disadvantage is that the competitive strength of projects is still not identical to the sustainable competitive advantage of an enterprise since competitors quickly copy any price or quality advantages of innovative projects, and consequently their economic benefits rapidly disappear. Also, there are some complaints due to the reduction of project competitiveness according to the assessment of the pricequality ratio, which does not consider the degree of its innovativeness and which is of great importance in positioning the project in the market.

In addition, the application of the considered group of methods requires comparison to similar innovative projects. At the same time, the development of commodity-money relations leads to ever-more-aggravating differences in the economic conditions of enterprises, their ever-increasing diversification, and the ever-greater differentiation of projects and services. It is becoming increasingly difficult to determine the clear geographical boundaries of a particular market and to establish a list of competing projects, leading to the low applicability of such methods for assessing an enterprise's competitiveness.

However, the main disadvantage of this approach is that it only allows one to gain a very limited understanding of the advantages and disadvantages of the enterprise since the measure of its competitiveness hinges on the competitiveness of innovative projects and thus does not consider other aspects of its activities. After all, the competitiveness of such projects reflects the level of demand for innovation, and the competitiveness of an enterprise reflects the level of business efficiency.

\section{References}

Abdrakhmanova, M., Mutanov, G., Mamykova, Z., \& Tukeyev, U. (2018). Agents Interaction and Queueing System Model of Real Time Control of Students Service Center Load Balancing. Lecture Notes in Computer Science (including subseries Lecture Notes in Artificial Intelligence and Lecture Notes in Bioinformatics), 11055 LNAI, 349-359 (pp. 349-359). https://doi.org/10.1007/978-3-319-98443-8_32

Adamczyk, M., Betlej, A., Gondek, J., Ohotina, A. 2019. Technology and sustainable development: towards the future?, Entrepreneurship and Sustainability Issues, 6(4), 2003-2016. http://doi.org/10.9770/jesi.2019.6.4(32)

Atari, S., Bakkar, Y., Olaniyi, E. O., Prause, G. 2019. Real options analysis of abatement investments for sulphur emission control compliance. Entrepreneurship and Sustainability Issues, 6(3), 1062-1087. http://doi.org/10.9770/jesi.2019.6.3(1)

Bente Villadsen, M. J. (2017). Discounted Cash Flow Models. In M. J. Bente Villadsen, Risk and Return for Regulated Industries (pp. 97116). Academic Press.

Bohdaniuk, O., Buriak, R., Savchuk, V. 2019. Competitiveness of horticultural products as a precondition of industry development. Entrepreneurship and Sustainability Issues, 6(4), 1587-1601. https://doi.org/10.9770/jesi.2019.6.4(3)

Bringer, J. D., Johnston, L. H., \& Brackenridge, C. H. (2006). Using computer-assisted qualitative data analysis software to develop a grounded theory project. Field methods, 18(3), 245-266.

Carrillo-Hermosilla, J., Del Río, P., \& Könnölä, T. (2010). Diversity of eco-innovations: Reflections from selected case studies. Journal of cleaner production, 18(10-11), 1073-1083. https://doi.org/10.1016/j.jclepro.2010.02.014.

Cluzel, F., Yannou, B., Millet, D., \& Leroy, Y. (2016). Eco-ideation and eco-selection of R\&D projects portfolio in complex systems industries. Journal of Cleaner Production, 112, 4329-4343. https://doi.org/10.1016/j.jclepro.2015.08.002.

Cornell University, INSEAD, and WIPO (2018). The Global Innovation Index 2018: Energizing the World with Innovation. Ithaca, Fontainebleau, and Geneva.

Dudin, M.N., Ivashchenko, N.P., Gurinovich, A.G., Tolmachev, O.M., Sonina, L.A. 2019. Environmental entrepreneurship: characteristics of organization and development. Entrepreneurship and Sustainability Issues, 6(4), 1861-1871. http://doi.org/10.9770/jesi.2019.6.4(22) 


\section{ENTREPRENEURSHIP AND SUSTAINABILITY ISSUES}

ISSN 2345-0282 (online) http://jssidoi.org/jesi/

2019 Volume 6 Number 4 (June)

http://doi.org/10.9770/jesi.2019.6.4(41)

Dutra, C. C., Ribeiro, J. L. D., \& de Carvalho, M. M. (2014). An economic-probabilistic model for project selection and prioritization. International Journal of Project Management, 32(6), 1042-1055. https://doi.org/10.1016/j.ijproman.2013.12.004 .

Eddelani, O., El Idrissi, N. E., Monni, S. 2019. Territorialized forms of production in Morocco: provisional assessment for an own model in gestation, Insights into Regional Development 1(1): 6-18. https://doi.org/10.9770/ird.2019.1.1(1)

Huang, X., Zhao, T., \& Kudratova, S. (2016). Uncertain mean-variance and mean-semivariance models for optimal project selection and scheduling. Knowledge-Based Systems, 93, 1-11.

Jeng, D. J. F., \& Huang, K. H. (2015). Strategic project portfolio selection for national research institutes. Journal of Business Research, 68(11), 2305-2311.

Karasakal, E., \& Aker, P. (2017). A multicriteria sorting approach based on data envelopment analysis for R\&D project selection problem. Omega, 73, 79-92.

Ketokivi, M., \& Choi, T. (2014). Renaissance of case research as a scientific method. Journal of Operations Management, 32(5), 232-240.

Lambrechts, W., Gelderman, C. J., Semeijn, J., \& Verhoeven, E. (2019). The role of individual sustainability competences in eco-design building projects. Journal of Cleaner Production, 208, 1631-1641. https://doi.org/10.1016/j.jclepro.2018.10.084

Leach, T. H., Winslow, L. A., Acker, F. W., Bloomfield, J. A., Boylen, C. W., Bukaveckas, P. A., ... \& Farrell, J. L. (2018). Long-term dataset on aquatic responses to concurrent climate change and recovery from acidification. Scientific data, 5, 180059. doi:

10.1038/sdata.2018.59 (2018).

Levidow, L., Lindgaard-Jørgensen, P., Nilsson, Å., Skenhall, S. A., \& Assimacopoulos, D. (2016). Process eco-innovation: assessing mesolevel eco-efficiency in industrial water-service systems. Journal of Cleaner Production, 110, 54-65.

https://doi.org/10.1016/j.jclepro.2014.12.086

López, F. J. D., \& Montalvo, C. (2015). A comprehensive review of the evolving and cumulative nature of eco-innovation in the chemical industry. Journal of cleaner production, 102, 30-43. https://doi.org/10.1016/j.jclepro.2015.04.007

Montalvo, C., Diaz-Lopez, F., \& Brandes, F. (2011). Eco-innovation Opportunities in Nine Sectors of the European Economy. European Sector Innovation Watch. European Commission, Directorate General Enterprise and Industry, Brussels.

Mutanov, G. (2015). Mathematical Methods and Models in Economic Planning, Management and Budgeting (p. 364). Springer Berlin Heidelberg.

Mutanov, G., Milosz, M., Kozhanova, A. (2018). Systematically dynamic model-building approach of oil company. Journal of Engineering and Applied Sciences, 13 (10), 3396-3401. http://medwelljournals.com/abstract/?doi=jeasci.2018.3396.3401

Mutanov, G., Milosz, M., Saxenbayeva, Z., \& Kozhanova, A. (2018). Investments Decision Making on the Basis of System Dynamics. Studies in Computational Intelligence, (769), 293-303. https://doi.org/10.1007/978-3-319-76081-0 25

Padhy, R. K., \& Sahu, S. (2011). A real option based Six Sigma project evaluation and selection model. International Journal of Project Management, 29(8), 1091-1102. https://doi.org/10.1016/j.ijproman.2011.01.011

Reid, A., \& Miedzinski, M. (2008). Eco-innovation: final report for sectoral innovation watch. SYSTEMATIC Eco-Innovation Report.

Scarpellini, S., Valero-Gil, J., \& Portillo-Tarragona, P. (2016). The "economic-finance interface" for eco-innovation projects. International Journal of Project Management, 34(6), 1012-1025. https://doi.org/10.1016/j.ijproman.2016.04.005

Shvetsova, O.A.; Rodionova, E.A.; Epstein, M. Z. 2018. Evaluation of investment projects under uncertainty: multi-criteria approach using interval data. Entrepreneurship and Sustainability Issues, 5(4), 914-928. http://doi.org/10.9770/jesi.2018.5.4(15)

Stone, P. J., Dunphy, D. C., \& Smith, M. S. (1966). The general inquirer: A computer approach to content analysis. 


\section{ENTREPRENEURSHIP AND SUSTAINABILITY ISSUES}

ISSN 2345-0282 (online) http://jssidoi.org/jesi/

2019 Volume 6 Number 4 (June)

http://doi.org/10.9770/jesi.2019.6.4(41)

Triebswetter, U., \& Wackerbauer, J. (2008). Integrated environmental product innovation in the region of Munich and its impact on company competitiveness. Journal of Cleaner Production, 16(14), 1484-1493. https://doi.org/10.1016/i.jclepro.2007.09.003

Tvaronavičienè, M. 2018. Towards sustainable and secure development: energy efficiency peculiarities in transport sector. Journal of Security and Sustainability Issues, 7(4), 719-725. https://doi.org/10.9770/jssi.2018.7.4(9)

Woodrum, E. (1984). "Mainstreaming" content analysis in social science: Methodological advantages, obstacles, and solutions. Social Science Research, 13(1), 1-19.

Yin, S., Ding, S. X., Xie, X., \& Luo, H. (2014). A review on basic data-driven approaches for industrial process monitoring. IEEE Transactions on Industrial Electronics, 61(11), 6418-6428.

Zhao, J., Yang, Y., Zhao, Q., \& Zhao, Z. (2017). Effects of ecological restoration projects on changes in land cover: A case study on the Loess Plateau in China. Scientific reports, 7, 44496.

Žižlavský, O. (2014). Net present value approach: method for economic assessment of innovation projects. Procedia-Social and Behavioral Sciences, 156, 506-512.

Galimkair MUTANOV is the academician of the National Academy of Science of the Republic of Kazakhstan, member of World Academy of Arts and Sciences, doctor of technical sciences, rector of Al-Farabi Kazakh National University. In 2014, the «Springer», the world-famous publishing house, published his book entitled the «Mathematical Methods and Models in Economic Planning, Management and Budgeting». The book got endorsement by the Nobel Prize winner in economics, John Nash.

ORCID ID: orcid.org/0000-0002-1375-1343

Sayabek ZIYADIN is the Professor, Doctor of economic science and Director of the Center for Economic Research at al-Farabi Kazakh National University. His work has attracted best research paper awards in both the database Scopus and the Clarivate. Research interests: tourism and regional development; innovation and digitalization; project management; sustainability.

ORCID ID: orcid.org/0000-0001-7219-1545

Aijaz SHAIKH is a PhD in Marketing from the University of Jyväskylä Business School (AACSB), Finland and holds a Professional Certification in Digital Marketing. Earlier, Aijaz completed his M.Sc. from Hanken School of Economics (AACSB / EQUIS), Finland. His academic specialty is digital marketing, digital consumer behavior, and shared / digital economy. Dr. Shaikh has completed various pedagogical training at the University of Jyväskylä in Finland.

ORCHID ID: orcid.org/0000-0001-5389-4384

Copyright (C) 2019 by author(s) and VsI Entrepreneurship and Sustainability Center

This work is licensed under the Creative Commons Attribution International License (CC BY).

http://creativecommons.org/licenses/by/4.0/

(c) (†) Open Access 